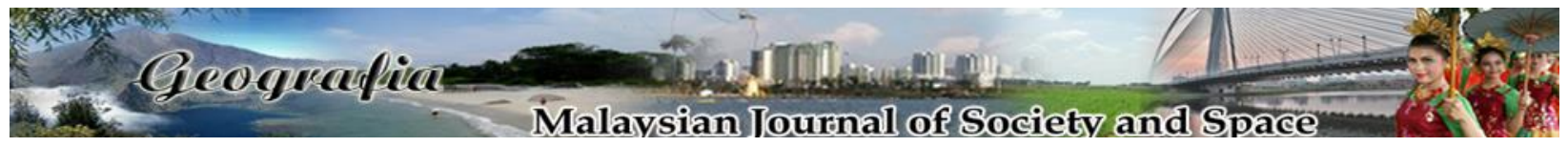

\title{
The 2019 Presidential Election in Nigeria: An analysis of the voting pattern, issues and impact
}

\author{
Babayo Sule \\ Department of Political Science, Faculty of Humanities Management and Social Sciences, \\ Federal University Kashere Gombe, Nigeria \\ Corresponding: Babayo Sule (email: babayosule@gmail.com)
}

Received: 9 March 2019; Accepted: 19 April 2019; Published: 14 May 2019

\begin{abstract}
The 2019 Presidential Election is one of the most keenly and closely contested in the history of Nigerian Presidential Elections since the colonial and post-independence period. The election was heralded with tensions, accusations and counter-accusations, intense campaign, trade of blames by the ruling and major opposition parties and other related issues. This study examined the process of the conduct of the 2019 Presidential Election, the outcome and analysis of the voting pattern and its implications. The work adopted both primary and secondary sources of data. The primary source is the direct participant observation where the author was part of the process of the election as a collation officer for the Presidential Election in one of the local governments in Nigeria. The research also observed directly on a live broadcast the presentation of the results by the state returning officers where the results were collected and used for analysis. The secondary sources include the use of books, journals and internet sources. The data obtained was presented in a thematic form using tables and statistical interpretations. The research discovered that the outcome of the 2019 General Election continued to reflect the voting pattern in Nigeria where ethno-religious and regional affiliations determine how the electorates choose their President even though, the two major contenders this time emerged from the same region unlike the previous situations. The research recommends that there is a need for massive enlightenment among the electorates towards choice of leaders based on performance and not sentiments.
\end{abstract}

Keywords: analysis, election, politics, president, Presidential Election, voting pattern

\section{Introduction}

Election is the process of choosing leaders in a democratic process where a legitimate change of government is constitutionally allowed (Johari, 2011). Election in Nigeria has been taking place since 1922 and since that period, election occurred continuously until 1960 when the political 
independence was gained from Britain. After political independence, election took place in 1964 but the democratic regime was short-lived because of bloody military coup. In 1979, Nigeria dropped the parliamentary system of government and switched to presidential system. The Aborted Third Republic in 1991 did not witnessed a smooth transition until in 1999 when the Fourth Republic emerged and remains the longest democratic transition in the history of the country (Sule et al., 2018).

Election takes place in Nigeria at different levels. In the Fourth Republic, from 1999 to the 2019 General Elections, there are seven electoral offices constitutionally including the Presidential, Senatorial, Federal House of Representatives, Gubernatorial, State House of Assembly, Chairmanship and Councillorship (Nigerian 1999 Constitution as amended). One of the most interesting episodes in Nigerian politics is the Presidential Election. This is because of the voting pattern and political behaviour of the Nigerian voters towards electing their leaders. This makes the battle for the Presidential seat intense, chaotic and threatening, sometimes to the extent of national disintegration. The culture of ethnic, religious and regional voting inherited from the nationalists during the colonial period spillover to the present era and it seems to be continuous (Sule et al., 2017).

This work is an investigation of the process of the conduct of the 2019 Presidential Election, the pattern of voting behaviour, an analysis of the outcome, the issues emanating from the contest and the anticipated implications of the pattern of the voting on the incoming government and the geopolitical zones in general.

\section{Literature review}

In this segment, a thorough critical review of some issues related to the subject matter of study are presented using some selected sub-themes that are most relevant to the field of study. As such, the following were discussed under the following sub-headings: Elections in Nigeria, voting pattern in Nigeria and Presidential Elections in Nigeria.

\section{Elections in Nigeria}

Election in Nigeria relies on two major legal documents which are the 1999 Constitution as Amended and the Electoral Act 2010. The Independent National Electoral Commission (INEC) is the agency that is saddled with the responsibility of the conduct of elections and other related matters such as registration and de-registration of political parties, regulating the conducts and activities of contestants and political parties and designing regulations for the electorates towards the conduct of the election proper. The INEC has been perceived as one of the challenges of electoral conduct in Nigeria due to alleged corruption, partiality, irregularities, shoddy preparations and lack of expertise and professionalism among others (The Centre for Public Policy Alternatives, 2015).

Election in Nigeria usually has the political culture and voting pattern of ethnicity, religion and regionalism which is part of the issues that are bedeviling the successful choice of good leaders in the country (Abdullahi, 2015). Closely related to the above is the politics of winning at all cost where elections in Nigeria are marred with rigging, violence, manipulation of results and intimidation of opposition and their supporters using the apparatus of security personnel and political thugs (Auwal, 2015). Election in Nigeria took the dimension of money politics where 
vote buying, godfatherism, bribery, corruption, overspending, violation of electoral rules and other irregularities affected the process and its outcome (Sule et al., 2018). The phenomenon of money politics reached its zenith in Nigerian politics during the 2015 Presidential Election.

The political elites found it expedient to manipulate religion as the easiest means of acquiring power because of their failure to deliver their responsibilities. Politics has been turned into a business venture in Nigeria for self-services and personal accumulation of wealth. The religious clerics are bought and corrupted by the politicians to sway the voters' opinion into submission to religious sentiments in politics. This has been reported by Sule et al. (2018).

The political culture in Nigeria is that of the politics of violence, zero-sum game, militarism, utilisation of thugs by politicians and the use of all available means to secure power at all cost including killings, political assassination, intimidation of opposition and voters. Because of the elites' nature of capturing power at all cost for personal gain, election in Nigeria is turned into a war-like affair (Falola \& Heaton, 2008).

Election can thus, be held peacefully, safely and fairly if the process of the conduct is improved. One of the ways is to prevent rigging through e-voting which will make the voters' choice to count and to ensure policy compliance from the politicians. There should be aggressive public awareness creation on the evil consequences of involvement in rigging, violence and all sorts of manipulation from the electorates. Furthermore, election can be held safely if the politics of ethnicity, religion and regionalism are mitigated.

\section{Voting pattern in Nigeria}

History is one of the major factors behind the voting pattern in Nigerian politics and electoral process. Nigeria as it is today, was a formation of an arbitrary colonial interest where the British colonisers decided in 1914 to amalgamate the Northern and Southern Protectorates under Governor Lord Lugard and named it the British Colony of Nigeria. After political independence, the multi-ethnic, multi-religious and contiguous regions that formed the present-day Nigeria failed to melt towards national integration because the populace is identifying their ethnic identities as more important than the national unity (Falola \& Heaton, 2008).

Voters' turnout determines the voting pattern of the electorates also during Presidential Elections in this country. Political apathy is recorded in General Elections in Nigeria because of the attitude of the political office holders who promised earth and heaven to the voters during electioneering campaign and after assumption of power, reneged against their promises and transformed themselves into emperors who enrich themselves from the public treasury at the expenses of developmental projects (Sule et al., 2017). Voting pattern in Nigeria can take three major approaches; the sociological, party identification and rational choice (Mudasiru, 2015).

\section{Presidential elections in Nigeria}

Presidential Election in Nigeria started during the Second Republic (1979-1984) when the country dropped the parliamentary system of government after the bloody coup in 1966. From 1979 to date, Presidential Election took place nine (9) times in the history of the country. The first two elections occurred in the Second Republic in 1979 and 1983. Another took place in 1991 during the Aborted Third Republic which was eventually annulled. In the Fourth Republic, six (6) Presidential Elections took place during 1999, 2003, 2007, 2011, 2015 and 2019. 
An analysis of the Presidential Election in Nigeria will reveal a pattern of voting behaviour where the electorates are voting according to ethnic, religious and regional belongings. For instance, the 1979 Presidential Election disclosed that the three major contenders; Alhaji Shehu Shagari of National Party of Nigeria (NPN), Obafemi Awolowo of Unity Party of Nigeria (UPN) and Dr Nnamdi Azikiwe of the Nigerian Peoples Party (NPP) gained their votes from their respective political regions. The same phenomenon replicated itself in the 1983 Presidential Election (Akinboye \& Anifowose, 2008; Sule et al., 2017). In the Fourth Republic, the Presidential Election was contested six times in 1999, 2003, 2007, 2011, 2015 and 2019 and all the contests present ethnic and religious influence among the voters either directly or indirectly.

In 2011, President Jonathan from the South contested under the platform of PDP while Muhammadu Buhari under the Congress for Progressive Change (CPC). The votes were shared regionally with Buhari winning in the North and Jonathan in the South. Jonathan won the contest and the same contestants resurfaced in 2015 but, this time around, Buhari won (Sule et al., 2018). The 2019 Presidential Election saw another dimension where the two major strong contenders; President Muhammadu Buhari of the APC and Alhaji Atiku Abubakar of the PDP emerged both from the North and both of them are from the Hausa/Fulani ethnic group and are also Muslims by religion. However, the voting pattern indicates a surprising result where the Hausa/Fulani Muslims voted massively for President Muhammadu Buhari while the Northern Christians and the Southsouth and Southeast voted for Atiku with the votes spoilt between the two in the Southwest. These are shown in the tables in the discussion section. The summary of the history of Presidential Elections in Nigeria is presented below in a tabular form.

Table 1. Summary of the results of Presidential Elections in Nigeria (1979-2019) for the winners and runners up

\begin{tabular}{|c|c|c|c|c|c|c|c|}
\hline Year & Party & Candidate & Scores & Party & Candidate & Scores & Winner \\
\hline 1979 & NPN & Alhaji Shehu Shagari & $5,668,857$ & UPN & Obafemi Awolowo & $4,916,651$ & NPN \\
\hline 1983 & NPN & Alhaji Shehu Shagari & $12,081,471$ & UPN & Obafemi Awolowo & $7,907,209$ & NPN \\
\hline 1991 & SDP & MKO Abiola & $8,341,309$ & NRC & Alhaji Bashir Tofa & $5,952,087$ & SDP \\
\hline 1999 & PDP & Olusegun Obasanjo & $18,738,154$ & $\mathrm{AD}$ & Olu Falae & $7,907,209$ & PDP \\
\hline 2003 & PDP & Olusegun Obasanjo & $24,456,140$ & ANPP & Muhammadu Buhari & $12,710,022$ & PDP \\
\hline 2007 & PDP & Umaru Musa Yaradua & $24,638,063$ & ANPP & Muhammadu Buhari & $6,605,299$ & PDP \\
\hline 2011 & PDP & Goodluck Jonathan & $22,495,187$ & $\mathrm{CPC}$ & Muhammadu Buhari & $12,214,853$ & PDP \\
\hline 2015 & APC & Muhammadu Buhari & $15,424,921$ & PDP & Goodluck Jonathan & $12,853,162$ & $\mathrm{APC}$ \\
\hline 2019 & APC & Muhammadu Buhari & $15,191,847$ & PDP & Alhaji Atiku Abubakar & $11,262,978$ & APC \\
\hline
\end{tabular}

Source: Compiled by the author from analysis on the Cable Newspaper March 2019.

The results of the Presidential Elections in the history of Nigeria are clearly pointing towards ethnic, religious and regional voting for instance, the 1979 Presidential election was between a northerner Alhaji Shehu Usman Aliyu Shagari and a southerner Chief Obafemi Awolowo and the same phenomenon resurfaced itself in the 1983 Presidential Election. A detailed analysis of the result disclosed that voters cast their votes based on the candidates' ethnic, religious and regional background. The same can be said of the 1999, 2003, 2011 and 2015 General Election. The only exceptions are that of the 1991, 2007 and 2019 General Elections where the winners and runners-up emerged from either the same region or the same religious group. 


\section{Methods and study area}

The work relied on both primary and secondary sources of data collection and a qualitative method of data analysis. The primary sources are the direct participant observation by the author being an active part of the 2019 Presidential Election process as a collation officer in Gombe Local Government. In addition to this, the author participated in the process of live declaration of the result via television channel called "Channel' where the author gathered primarily the raw results, compiled them, analysed them and interpret them in the discussion section.

The secondary sources involve books, journals, newspapers, internet sources and existing relevant materials on the subject matter. The secondary sources were used for a critical review of related literature, formation of theoretical framework to strengthen the arguments in the discussions.

The data gathered were presented and analysed using a qualitative method of data analysis where themes were formed in a sub-heading for discussions. Tables were used for the presentation of some statistical figures such as percentage of the voters' turnout, parties' performance in the election and the margin of win as well as other related issues.

\section{Theoretical framework}

This work adopted the Rational Choice Theory of Election in explaining the context of this work. The Rational Choice Theory of Election is a political economy approach towards understanding the nature and pattern of voters' choice during election in a particular democratic setting. The Theory originates from the writings of Anthony Downs (1957) in his discourse of "An Economic Theory of Democracy". Another scholar behind the postulation of this theory is Kenneth Arrow (1986).

The Rational Choice Theory of Election identifies that political behaviour and voting pattern of the electorates is a rational choice based on some indicators such as economic benefit, resources allocation, distribution of goods and services, allocation of juicy political offices and favour (Downs, 1957; Arrow, 1986). This view has been consolidated by Farber (2009). Rational Choice Theory of Election is either evaluative or non-evaluative according to Downs (1957) and Arrow (1986). Evaluative is the process of measuring and evaluating the performances of regimes to determine whether they deserve voters' choice or not and, in this regard, rationality is based on performance measurement. The non-evaluative is based on clientelistic considerations such as favouritism, patronage, ethnicity, religion, regionalism and family. Lindberg \& Morrison (2008) observed that elections in African countries are mostly considered on clientelistic rationalism where the ethnic, religious and regional cleavages are given much consideration. Furthermore, Lindberg and Weghorst (2010) identified what they called "Swing votes" in developing democracies like Nigeria where they analysed that ethnic, religious, patronage and clientel satisfaction of the voters when measured with evaluation of performances of the leaders in office can influence the outcome of an election.

The theory is directly applicable within the context of this study since voting is recognised as a rational choice based on performances and clientel considerations. The results of the past Presidential Elections in Nigeria and that of the recently concluded 2019 is a good example of how the voters give much emphasis on ethnic, religious and regional rationality than performances. 


\section{Results and discussion}

This section presents the analysis of the data gathered by the researcher for interpretation and research findings. The discussion was made through the use of tripartite application of concepts including the primary data, existing literature and theoretical framework to support each other.

\section{The 2019 Presidential Election: A general analysis}

The 2019 Presidential Election as usual in Nigeria was heralded with tension, blame games, anticipated violence, campaign of calumny, threats and the desire to win at all cost. It was another presentation of the litmus test for Nigerian democratisation. In the first place, over 70 political parties were registered and about seventy-three (73) parties fielded candidates for the Presidential Election. The parties that fielded candidates for the election are presented in the table below.

Table 2. Political parties that contested for the 2019 Presidential Election in Nigeria

\begin{tabular}{|c|c|c|}
\hline Party & Presidential candidate & $\begin{array}{r}\text { Vice President } \\
\end{array}$ \\
\hline $\mathrm{A}$ & Isaac Ositelu & Lawal Muhammad \\
\hline AA & Abdulrashid Baba & Uchendu Ozoka \\
\hline $\mathrm{AAC}$ & Omoyele Sowore & Rabiu Rufai \\
\hline AAP & Chike Ukaegbu & Safiya Ogoh \\
\hline ABP & Shipi Godia & Okwuanyasi Shaliat \\
\hline $\mathrm{ACD}$ & Nwokeafor Ikechukwu & Ali Abdullahi \\
\hline ACPN & Obiageli Ezekwesili & Ganiyu Galadima \\
\hline $\mathrm{ADC}$ & Obadiah Mailafia & Nasiru Tanimowo \\
\hline ADP & Yusuf Yabaji & Olateru Martins \\
\hline AGA & Nwachukwu Nwabuiku & Tijjani Ali \\
\hline AGAP & Umenwa Godwin & Ibrahim Olaika \\
\hline ANDP & Yusufu Obaje & Sule Ganiyu \\
\hline ANN & Fela Durotoye & Khadijah Abdullahi-Iya \\
\hline ANP & Shittu Moshood & Okere Evelyn \\
\hline ANRP & Tope Fasua & Yakubu Zakari \\
\hline APA & Aliyu Ibrahim & Adeleke Aderemi \\
\hline APC & Muhammadu Buhari & Yemi Osinbajo \\
\hline APDA & Shittu Mohammed & Olayemi Mahmood \\
\hline APGA & John Gbor & Gerald Chukwueke \\
\hline APM & Mamman Yusuf & Duru Nwabueze \\
\hline APP & Obinna Ikeagwuonu & Omotosho Emmanuel \\
\hline ASD & John Dara & Abubakar Salihu \\
\hline AUN & Angela Johnson & Zayyanu Abubakar \\
\hline BNPP & David Eze-Iyamu & Kofar Umar \\
\hline $\mathrm{CC}$ & Geff Ojinika Chizee & Yakubu Usman \\
\hline CAP & Lewis Abah & Micheal Okojie \\
\hline CNP & Emmanuel Etim & Adeola Zainab \\
\hline DA & Frank Ukonga & Musa Saidu \\
\hline DPC & Awosola Ulusola & Seiyafa Fetepigi \\
\hline DPP & Felix Osakwe & Mohammed Ali \\
\hline FJP & John Onwubiya & Ahmad Muhammad \\
\hline FRESH & Chris Okotie & Bintu Adefila \\
\hline GDPN & Davidson Akhimien & Ibrahim Hamman \\
\hline GPN & Samuel Eke & Hadiza Musa \\
\hline
\end{tabular}




\begin{tabular}{|c|c|c|}
\hline HDP & Albert Owuru & Yahaya Shaba \\
\hline ID & Nnamdi Madu & Adamu Abubakar \\
\hline JNPP & Sunday Chukwu-Eguzolugu & Salihu Imam \\
\hline KP & Adesina Fagbenro-Byron & Ummar Abbas \\
\hline LM & Kris David & Azael Vashi \\
\hline LP & Usman Mohammed & Tom Akpan \\
\hline MAJA & Olufunmilayo Adesanya-Davies & Anthony Ibeneme \\
\hline MMN & Isah Bashayi & Oluwatoyin Adepoju \\
\hline MPN & Hamisu Santuraki & Chinwe Ufondu \\
\hline NAC & Rabia Hassan & Chineme Uhuegbu \\
\hline NCMP & Babatunde Ademola & Aisha Tataji \\
\hline NCP & Yunusa Salisu & Funmi James \\
\hline NDCP & Johnson Edosomwan & Nasiru Mohammed \\
\hline NDLP & Robinson Akpua & Umaru Ahmadu \\
\hline NEPP & Paul Ishaka & Akinfelami Vincent \\
\hline NFD & Asukwo Archibong & Ite Donald-Ekpo \\
\hline NIP & Eunice Atuejide & Muhammad Bello \\
\hline NNPP & Ike Keke & Johnson Omede \\
\hline NPC & Maimuna Maina & Yetunde Oluwale \\
\hline NPM & Usman Ibrahim & Onwa Nwafor-Orizeu \\
\hline NUP & Moses Ajibiowu & Micheal Idoko \\
\hline PCP & Felix Nicholas & Baba Ado \\
\hline PDP & Atiku Abubakar & Peter Obi \\
\hline PPA & Peter Ameh & Kehinde Edun \\
\hline PPC & Victor Okhai & Iyan Tama Hamisu \\
\hline PPN & Hamza Al Mustapha & Robert Opara \\
\hline PT & Gbenga Olawope-Hashim & Nwankwo Agwuncha \\
\hline RAP & Israel Nonyerem Davidson & Dawud Hassan \\
\hline RBNP & Chukwudi Osuala & Muhammad Falali \\
\hline $\mathrm{RP}$ & Nseobong Nsehe & Mohammed Abuh \\
\hline SDP & Aligned with APC & \\
\hline SNC & Thomas Da Silva & Aisha Muhammad \\
\hline SNP & Ahmad Buhari & Nwagwu Kingsley \\
\hline UDP & Ishiaka Balogun & Shuaibu Mohammed \\
\hline UP & Mark Emmanuel & Okeke Moses \\
\hline UPN & Ahmed Inuwa & Echemor Nkwocha \\
\hline WTPN & Nwangwu Uchenna & Olanrewaju Adebowale \\
\hline YES & Ali Soyode & Balkisu Abdullahi \\
\hline YPP & Kingsley Moghalu & Umma Getso \\
\hline
\end{tabular}

Source: www.inec.org (compiled and tabulated by the author March 2019).

The table above indicated a history being made where for the first time in the electoral history of Presidential Election in Nigeria a number of 73 parties contested. The two major contenders in APC and PDP were identified in the table with a red marking for easy identification. The large number of parties made the 2019 Presidential Election a unique affair in comparison with the previous Presidential Elections in the country.

The result of the 2019 Presidential Election recorded the lowest voter turnout in comparison with that of the 2011 and 2015. In 2011, a turnout of 56.4\% was recorded, in 2015, a 46.8\% voters' turnout was recorded while in the 2019 Presidential Election, only 39.09\% turnout was recorded. Some of the reasons for this low turnout is political apathy, postponement of the Election from $14^{\text {th }}$ February 2019 to $23^{\text {rd }}$ March 2019. The statistical details of the 2019 Presidential Election result indicating the voting pattern state by state and the performance of the 
major candidates and their parties is presented in Appendix A of this work located after the reference section (Refer to the Appendix A for more details).

The result indicates a voting pattern of the normal Nigerian political culture as observed by Sule et al. (2017) and Mudasiru (2015). The Rational Choice Theory of Election too is applicable here especially the 'Swing Votes' syndrome postulated by Lindberg and Weghorst (2010) where ethnic affiliation, religion and region is given much emphasis than performance (See Appendix A).

The Presidential Election in 2019 set another dimension in Nigerian political history because despite the fact that the two major contenders are Muslims, a new scenario emerged in which the APC candidate was identified by religious clerics and other manipulators of religion as pure and moral while the PDP candidate was identified as corrupt and amoral. Furthermore, the main issue hinged on the allegations that the PDP candidate was corrupt. This allegation was supported by the elite class in the country while the APC candidate was portrayed as incorruptible and promasses despite the tacit overlooked of corrupt practices by his closest officials in his last four years in office.

The 2019 Presidential Election has many impacts on the socioeconomic and sociopolitical aspects of the Nigerian state. The incumbent President who won in the Election was pursuing aggressive infrastructural construction in the country which is believed to have future socioeconomic benefits to the people. He also embarked on economic diversification especially in agriculture, social investments programmes which all have economic and social benefits. Hadn't it been the PDP candidate win, he may stop the policies and initiate his own because of the usual culture of discontinuity in policies in Nigeria. politically, the power sharing is balanced because there was a gentleman agreement and understanding that after the two-term tenure, the power will shift to the southern part of the country but, if the PDP is assumed to have win, this arrangement will be reversed because the winner may have another fresh two-term tenure to spend and that will translate into straight 12 years Presidential tenure for the North.

\section{Voting pattern and geopolitical distribution}

The voting pattern and geopolitical distribution of the 2019 Presidential Election indicate the continuous culture of Nigerian voters towards their leaders in an election. The APC candidate has a stronghold of the Northwest and Northeast as the traditional supporting ground that he has since his inception of contest for the Presidential seat in 2003 because of religious, ethnic and regional factor since he is a Hausa/Fulani Muslim from the dominant region of his ethnic and religious belonging. The PDP nearly became an official party of the Southsouth and Southwest since 1999 most especially with the emergence of President Goodluck Jonathan from the Southsouth in 2011. As expected, the Northwest and Northeast voted massively for President Buhari while the Southeast and Southsouth voted for Alhaji Atiku Abubakar. This is because President Buhari was considered in the Northwest and Northeast as the charismatic leader that is religious, incorruptible and a dominant Hausa/Fulani that has been contesting from the region since 2003 with overwhelming support whereas Atiku Abubakar is perceived by the Northwest and Northeast as corrupt, elite-oriented and pro-southern part of the country. The Southeast and Southsouth saw President Buhari as religious bigot and ethnic chauvinist in which Atiku was not to them. Besides, PDP is a strongest and dominant party in the Southeast and Southsouth, hence any candidate in that party irrespective of his background may get the highest votes there. 
The Northcentral was shared among the two leading contenders with the APC candidate winning in four of the six states but with a narrow margin. The Southwest zone presented a surprise because it is seen as one of the strongholds of APC. The Action Congress of Nigeria $(\mathrm{ACN})$, and the political godfather in the region Asiwaju Bola Ahmed Tinubu spearheaded the alliance and formation of the APC to have access to corridors of power and possibly to have the power returned to the Southwest after the eight years of President Buhari. The APC national leader Bola Ahmed Tinubu is from there and the zone benefitted more than any other in terms of major political offices and infrastructure in the 4-years of the APC regime. However, the votes seemed to be shared almost equally between the APC and the PDP in the region which indicates a low level of patronage and a political culture of that geopolitical zone. This analysis is presented below in the table below.

Table 4. Voting pattern in geopolitical zones of the 2019 Presidential Election in Nigeria

\begin{tabular}{lcccccc}
\hline Geopolitical zones & APC & Percentage & PDP & Percentage & Differences & Winner \\
\hline Northeast & $3,238,783$ & 74.36 & $1,116,873$ & 25.64 & $2,121,910$ & APC \\
Northcentral & $2,313,375$ & 54.92 & $1,763,772$ & 45.08 & 549,603 & APC \\
Northwest & $5,995,651$ & 72.45 & $2,280,465$ & 27.55 & $3,715,186$ & APC \\
Southeast & 403,968 & 19.26 & $1,693,485$ & 80.74 & $1,289,517$ & PDP \\
Southsouth & $1,051,396$ & 32.01 & $2,233,232$ & 67.99 & $1,181,836$ & PDP \\
Southwest & $2,036,450$ & 53.41 & $1,776,670$ & 46.59 & 259,780 & APC \\
FCT Abuja & 152,224 & 36.77 & 259,997 & 63.23 & 110,773 & PDP \\
\hline Seven Zones & $15,191,847$ & 55.54 & $11,262,978$ & 41.18 & $3,928,869$ & APC WON \\
\hline
\end{tabular}

Source: Analysed and computed by the author March 2019.

The voting pattern from the above table shows that the APC candidate secured huge votes from the Northeast and Northwest to emerge victorious while the PDP candidate secured his major votes from the Southeast and Southsouth. This is because President Buhari is perceived in these two regions as religious bigot and ethnic chauvinist while Atiku Abubakar as a true nationalist with alliance across the nation and also because of the fact that the PDP has been the dominant party in the regions since 1999 and all the previous Presidential candidates won in a landslide victory in the regions under the platform of the PDP. The remaining two zones of Northcentral and Southwest were shared between the two major contenders. The voting pattern will take a different dimension in 2023 when the Presidency may likely shift to the Southwest where a larger voter turnout may be witnessed and a lesser one in the North. This is so because each region in Nigeria voted massively when a candidate is from that region with similar religion and ethnic group since the politics of manipulation of religion and ethnicity have gained ground in the country beyond redemption for many decades. This view has been justified by Falola $\&$ Heaton (2008), Sule et al. (2018) and Mudasiru (2015). Additionally, the Rational Choice Theory of Election can explain the reason behind this voting pattern because the Northeast and Northwest being a Hausa/Fulani and a Muslim dominated area voted hugely for President Buhari's APC obviously due to the perception that he is closer to them than Atiku of PDP. 


\section{Conclusion}

The paper concludes that the 2019 Presidential Election has similitude with the previous Presidential Elections in Nigeria from 1979 in terms of voting pattern and political behaviour. The electorates voted for their Presidents with much emphasis on ethnicity, religion and regionalism. The phenomenon seems to continue despite the development of democracy in the country. The paper also concludes that the 2019 Presidential Election differs in many ways from the previous Presidential Elections in the history of the country. One of the ways is the higher number of political parties with a total registered number of parties up to 91 and 71 of them fielded candidates for the Presidential contest. The work therefore recommends that for a voting pattern to change in Nigeria towards evaluation of performance instead of sentimental cleavages there must be parties with political ideology that can distribute power and resources based on equality and equity instead of clientelism. It is also recommended that there is a need for an intensive and aggressive enlightenment of the voters towards political socialisation.

\section{References}

Abdullahi, S.A. (2015). Youth, political parties and electoral violence in Nigeria. In Mohammed, H. (Ed.) The patterns and dynamics of party politics in Nigeria's Fourth Republic. Kano, Hallmark Publishing Nigeria LTD.

Akinboye, S.O., \& Anifowose, R. (2008). Nigerian government and politics. In Anifowose, R., \& Enemuo, F. (Eds.) Elements of politics. Lagos, Sam Iroanusi Publishers.

Arrows, K. (1951) Social values and individual values. New York, John Wiley \& Sons.

Auwal, A. (2015). Political parties and electoral misconduct in Nigeria. In Mohammed, H. (Eds.). The patterns and dynamics of party politics in Nigeria's Fourth Republic. Kano, Hallmark Publishing Nigeria LTD.

Downs, A. (1957). An economic Theory of Democracy. New York, Harper Collins Publishers.

Falola, T., \& Heaton, M. (2008). A history of Nigeria. Cambridge, Cambridge University Press.

Farber, H.S. (2009). Rational choice and voter turnout: Evidence from Union Representation Elections. CEPS Working Paper.

Federal Government of Nigeria. (2016). Nigerian 1999 Constitution as amended. Abuja, Federal Government Publication.

Johari, J.C. (2011). Comparative politics. New Delhi, Sterling Publishers.

Lindberg, S.I., \& Morrison, M. (2008). Are African voters really ethnic or clientelistic? Survey evidence from Ghana. Political Science Quartely, 8(4), 89-98.

Lindberg, S.I., \& Weghorst, K.R. (2010). Are swing voters instruments of democracy or farmers of clientelism: Evidence from Ghana. The QOG Institute Quality of Government.

Mudasiru, S.O. (2015). Ethnicity and the voting pattern in Nigeria's 2015 General Elections: The case of Lagos State. The Electorate Institute Abuja. Retrieved from https://www.inecnigeria.org

Sule, B., Azizuddin, M., Sani, M., \& Mat, B. (2017). Political party financing and corruption in Nigeria's Fourth Republic: The case of 2015 General Elections. Arts Social Sciences Journal, 8(1), 276-298. 
Sule, B., Azizuddin, M. Sani, M., \& Mat, B. (2017). Political behaviour and voting pattern in Nigeria's Fourth Republic: The case of 2015 Presidential Election. Asia Pacific Journal of Education Arts and Sciences, 4(4), 1-13.

Sule, B., Sani, M., Azizuddin, M., \& Mat, B. (2017) Independent National Electoral Commission (INEC) and campaign financing monitoring in Nigeria: The 2015 General Election in Journal of International Studies, 13(1), 15-31.

Sule, B., Azizuddin, M., Sani, M., \& Mat, B. (2018). Godfatherism and political party financing in Nigeria: Analysing the 2015 General Election. Geografia: Malaysian Journal of Society and Space, 14(1), 1-14.

Sule, B. Azizuddin, M., Sani, M., \& Mat, B. (2018) Opposition political parties and democratic consolidation in Nigeria: Examining All Progressives Congress (APC) in the 2015 General Elections. Tamkang Journal of International Affairs, 21(4), 81-112.

Sule, B., Azizuddin, M., Sani, M., \& Mat, B. (2018). Impact of political party financing on integrity of 2015 General Election in Nigeria. Tamkang Journal of International Affairs, 22(2), 165-218.

The Centre for Public Policy Alternatives (CPPA). (2015). 2015 Presidential Election outcome: analyses \& implications. Retrieved from http://cpparesearch.org.

The Federal Government of Nigeria (1999). The Nigerian 1999 constitution as amended. Abuja, Federal Government Publication. 
APPENDIX A

The 2019 Presidential Election result in Nigeria across the 36 states and FCT Abuja

\begin{tabular}{|c|c|c|c|c|c|c|c|c|c|c|c|c|c|}
\hline States & $\begin{array}{l}\text { Registered } \\
\text { voters }\end{array}$ & $\begin{array}{c}\text { Total } \\
\text { collected } \\
\text { PVCS }\end{array}$ & $\begin{array}{c}\text { Voters' } \\
\text { turnout } \\
(\%)\end{array}$ & Accredited & APC & $\%$ & PDP & $\%$ & Others & $\%$ & Rejected & $\begin{array}{l}\text { Total votes } \\
\text { cast }\end{array}$ & Valid votes \\
\hline Abia & $1,932,892$ & $1,729,943$ & 20.90 & 361,561 & 85,058 & 26.31 & 219,698 & 67.96 & 18,535 & 5.73 & 21,180 & 344,471 & 323,291 \\
\hline Adamawa & $1,973,083$ & $1,788,706$ & 48.91 & 874,920 & 378,078 & 46.59 & 410,266 & 50.55 & 23,190 & 2.86 & 49,222 & 860,756 & 811,534 \\
\hline Akwa Ibom & $2,119,727$ & $1,933,362$ & 35.98 & 695,677 & 175,429 & 30.31 & 395,832 & 68.39 & 7,514 & 1.30 & 26,365 & 605,140 & 578,775 \\
\hline Anambra & $2,447,996$ & $2,071,714$ & 32.59 & 675,273 & 33,298 & 5.50 & 524,738 & 86.63 & 47,698 & 7.87 & 19,301 & 625,035 & 605,734 \\
\hline Bauchi & $2,462,843$ & $2,335,717$ & 46.04 & $1,075,330$ & 798,428 & 77.95 & 209,313 & 20.43 & 16,566 & 1.62 & 37,648 & $1,061,955$ & $1,024,307$ \\
\hline Bayelsa & 923,182 & 769,509 & 44.73 & 344,237 & 118,821 & 36.93 & 197,933 & 61.51 & 5,013 & 1.56 & 14,089 & 335,856 & 321,767 \\
\hline Benue & $2,480,131$ & $2,244,376$ & 35.02 & 786,069 & 347,668 & 47.70 & 356,817 & 48.95 & 24,427 & 3.35 & 34,960 & 763,872 & 728,912 \\
\hline Borno & $2,315,956$ & $2,000,228$ & 49.36 & 987,290 & 836,496 & 90.94 & 71,788 & 7.81 & 11,502 & 1.25 & 35,419 & 955,205 & 919,786 \\
\hline Cross River & $1,527,289$ & $1,387,314$ & 33.23 & 461,033 & 117,302 & 27.81 & 295,737 & 70.09 & 9,226 & 2.10 & 24,145 & 446,046 & 421,901 \\
\hline Delta & $2,845,274$ & $2,470,924$ & 36.09 & 891,647 & 221,292 & 26.67 & 594,068 & 71.59 & 14,402 & 1.74 & 52,492 & 882,254 & 829,762 \\
\hline Ebonyi & $1,459,933$ & $1,299,048$ & 30.16 & 391,747 & 90,726 & 25.26 & 258,573 & 71.99 & 9,832 & 2.75 & 20,263 & 379,747 & 359,131 \\
\hline Edo & $2,210,534$ & $1,726,738$ & 35.02 & 604,915 & 267,842 & 47.77 & 275,691 & 49.17 & 17,178 & 3.06 & 38,517 & 599,228 & 560,711 \\
\hline Ekiti & 909,967 & 666,591 & 57.18 & 381,132 & 219,231 & 57.52 & 154,032 & 40.42 & 7,869 & 2.06 & 12,577 & 393,709 & 381,132 \\
\hline Enugu & $1,944,016$ & $1,787,537$ & 25.33 & 452,765 & 54,423 & 12.93 & 355,553 & 84.45 & 11,038 & 2.62 & 30,049 & 451,063 & 421,014 \\
\hline FCT & $1,394,856$ & $1,026,920$ & 45.55 & 467,784 & 152,224 & 35.90 & 259,997 & 61.33 & 11,730 & 2.77 & 27, 457 & 451,408 & 423,951 \\
\hline Gombe & $2,394,393$ & $1,335,223$ & 45.25 & 604,240 & 402,961 & 72.71 & 138,484 & 24.99 & 12,758 & 2.30 & 26,446 & 580,649 & 554,203 \\
\hline Imo & $2,272,293$ & $1,702,178$ & 34.41 & 585,741 & 140,463 & 27.46 & 334,923 & 65.47 & 36,200 & 7.07 & 31,191 & 542,777 & 511,586 \\
\hline Kaduna & $3,932,492$ & $3,648,831$ & 48.18 & $1,757,868$ & 993,445 & 59.72 & 649,612 & 39.05 & 20,546 & 1.23 & 45,402 & $1,709,005$ & $1,663,603$ \\
\hline Kano & $5,457,747$ & $4,696,747$ & 42.72 & $2,006,410$ & $1,464,768$ & 77.45 & 391,593 & 20.71 & 34,773 & 1.84 & 73,617 & $1,964,751$ & $1,891,134$ \\
\hline Katsina & $3,230,230$ & $3,187,988$ & 51.09 & $1,628,865$ & $1,232,133$ & 79.22 & 308,056 & 19.80 & 15,284 & 0.98 & 63,712 & $1,619,185$ & $1,555,473$ \\
\hline Kebbi & $1,806,231$ & $1,718,180$ & 48.61 & 835,238 & 581,552 & 76.86 & 154,282 & 20.39 & 20,771 & 2.75 & 47,150 & 803,755 & 756,605 \\
\hline Kogi & $1,646,350$ & $1,435,751$ & 39.75 & 570,773 & 285,894 & 54.87 & 218,207 & 41.88 & 16,915 & 3.25 & 32,480 & 553,496 & 521,016 \\
\hline Kwara & $1,406,457$ & $1,149,969$ & 42.56 & 489,482 & 308,984 & 67.22 & 138,184 & 30.06 & 12,508 & 2.72 & 26,578 & 486,254 & 459,676 \\
\hline Lagos & $6,570,291$ & $5,531,389$ & 21.63 & $1,196,490$ & 580,825 & 53.31 & 448,015 & 41.12 & 60,727 & 5.57 & 67,023 & $1,156,590$ & $1,089,567$ \\
\hline Nassarawa & $1,617,786$ & $1,442,184$ & 42.55 & 613,720 & 289,903 & 49.92 & 283,947 & 48.89 & 6,928 & 1.19 & 18,621 & 599,399 & 580,778 \\
\hline Niger & $2,390,035$ & $2,173,204$ & 41.96 & 911,964 & 612,371 & 71.88 & 218,052 & 25.59 & 21,514 & 2.53 & 45,039 & 896,976 & 851,937 \\
\hline Ogun & $2,375,003$ & $1,694,867$ & 36.19 & 613,397 & 281,762 & 49.94 & 194,655 & 34.49 & 87,839 & 15.57 & 41,682 & 605,938 & 564,256 \\
\hline Ondo & $1,822,346$ & $1,478,460$ & 40.49 & 598,586 & 241,769 & 43.48 & 275,901 & 49.62 & 38,324 & 6.90 & 30,833 & 586,827 & 555,994 \\
\hline Osun & $1,680,498$ & $1,266,587$ & 57.87 & 732,984 & 347,634 & 48.64 & 337,377 & 47.21 & 29,671 & 4.15 & 17,200 & 731,882 & 714,682 \\
\hline Oyo & $2,934,107$ & $2,176,352$ & 41.58 & 905,007 & 365,229 & 42.29 & 366,690 & 42.46 & 131,612 & 15.25 & 54,549 & 891,080 & 863,531 \\
\hline Plateau & $2,480,455$ & $2,095,409$ & 51.26 & $1,074,042$ & 468,555 & 45.28 & 548,665 & 53.02 & 17,633 & 1.70 & 28,009 & $1,062,862$ & $1,034,853$ \\
\hline Rivers & $3,215,273$ & $2,833,101$ & 23.94 & 678,167 & 150,710 & 23.47 & 473,971 & 73.81 & 17,484 & 2.72 & 24,420 & 666,585 & 642,165 \\
\hline Sokoto & $1,903,166$ & $1,726,887$ & 55.02 & 950,107 & 490,333 & 56.24 & 361,604 & 41.47 & 19,954 & 2.29 & 54,049 & 925,107 & 871,891 \\
\hline Taraba & $1,777,105$ & $1,729,094$ & 43.73 & 756,111 & 324,906 & 45.58 & 374,743 & 52.57 & 13,228 & 1.85 & 28,687 & 741,564 & 712,877 \\
\hline Yobe & $1,365,913$ & $1,261,914$ & 47.63 & 601,059 & 497,914 & 89.01 & 50,763 & 9.08 & 10,688 & 1.91 & 26,772 & 586,137 & 559,365 \\
\hline
\end{tabular}

Source: Compiled and computed by the Author from the Collation Centre in Abuja via channel television on $25^{\text {th }}$ and $26^{\text {th }}$ February, 2019. 